DOI

\title{
ФОРМУВАННЯ ПОЗИТИВНИХ ЗМІН У РОБОТІ ВИКЛАДАЧІВ АКАДЕМІЇ НА ПІДСТАВІ АНКЕТУВАННЯ
}

\author{
Г. В. Дзяк, Т. О. Перцева, Л. Ю. Науменко, Г. В. Горбунова, С. В. Захаров, \\ Г. С. Канюка, Н. В. Ліхолетова
}

Державний заклад “Дніпропетровська медична академія Міністерства охорони здоров’я

України”

\section{FORMATION OF POSITIVE CHANGES IN THE WORK OF ACADEMY TEACHERS`ON THE BASIS OF QUESTIONING}

\author{
H. V. Dzyak, T. O. Pertseva, L. Yu. Naumenko, H. V. Horbunova, S. V. Zakharov, \\ H. S. Kanyuka, N. V. Likholetova \\ State Establishment "Dnipropetrovsk Medical Academy of Health Ministry of Ukraine”
}

\begin{abstract}
У статті звернено увагу на можливість за даними анкетування викладачів виявляти проблеми викладачів і формувати позитивні зміни в поліпшенні їх роботи.

In the article attention is paid to an opportunity to reveal problems of teachers according to questioning data and formation of positive changes in improvement of teachers`work.
\end{abstract}

Вступ. Проблема формування якісного викладацького складу вузів з метою забезпечення оптимального навчання і підготовки майбутніх фахівців на сучасному етапі розвитку суспільства залишається актуальною. Якість підготовки студентів значною мірою залежить від сформованого складу колективу викладачів вищого навчального закладу, їх готовності виконувати складні функції навчального, організуючого, виховного, дослідницького та інших напрямків. У свою чергу, це висуває проблему оцінки готовності викладача виконувати ці складні функції, розуміння тих факторів, які формують задоволеність роботою викладача вищої школи, підвищення мотивації до вдосконалення цієї важливої роботи та пошуку шляхів щодо формування позитивних змін у їх подальшій роботі.

Основна частина. Наприкінці 2014-2015 навчального року Центром психофізіологічних досліджень і практичної психології академії спільно з навчально-методичним кабінетом було проведено анкетування викладацького складу академії. Анкета складалася з 30 питань, які включали: вивчення думки викладачів щодо умов і змісту праці, психологічного клімату в колективах кафедр, стилю і

(ㄷ Г. В. Дзяк, Т. О. Перцева, Л. Ю. Науменко та ін. методів керівництва на різних рівнях управління, їх ставлення до нових форм контролю знань студентів; проблем нашого вузу в освітній сфері, інформаційному та матеріально-технічному забезпеченні в академії; щодо можливості оптимізації навчальнометодичної роботи; про рейтингову систему оцінки роботи викладачів; щодо планів на майбутнє тощо. Була забезпечена анонімність збору анкет, урни стояли в холах трьох навчальних корпусів. При відкритті в урнах виявилося 328 анкет. Розподіл за віком збігається зі структурою викладацького складу академії, а саме: 10,4 \% - до 30 років, 29 \% - від 31 до 40, 22,6 \% - від 41 до 50, 24,1 \% - від 51 до 60 років, 10,8 \% - старше 60 років. За стажем представлені всі групи викладачів: до 5 років - 19,2 \%, 5-10 років - 15,5 \%, 11-15 років - 17,4 \%, 16-20 років - 14,6 \%. Кожен третій мав 21 і більше років стажу (29,3 \% опитаних).

3 метою визначення найбільш значущих аспектів трудової діяльності викладачів в анкеті були представлені 8 основних аспектів, серед яких пропонувалося кожному викладачеві підкреслити 4 найважливіших для нього пункти. В результаті опитування було встановлено, що найбільш важливим аспектом трудової діяльності для викладача, на думку 62,5 \% опитаних, є “хороший психологічний 
клімат у колективі”. Другим за значимістю аспектом виявилася “можливість найбільш повної самореалізації в даній діяльності”. На це вказав кожен 2-й опитаний (51 \%). Третій значущий аспект - це “моральна підтримка з боку керівництва” (48,8 \%), а четвертий - “зміст праці” (48,2 \%).

При вивченні задоволеності викладачів різними сторонами їх діяльності встановлено, що більшість опитаних вважає свою викладацьку роботу цікавою (67,7 \%). 60,7 \% опитаних отримують задоволення від самого процесу викладання і результатів своєї праці. 60 \% респондентів задоволені працездатністю свого колективу, стилем і методами роботи керівників своїх кафедр. Однак кожного 2-го викладача не влаштовує забезпечення робочого місця матеріально-технічними засобами; 46,7 \% “обтяжують” рутинні робочі моменти, а 40,5 \% - побутові умови праці (температура в робочих приміщеннях, освітленість, шум і т. д.).

На питання “Які проблеми нашого вузу в освітній сфері, на Ваш погляд, є найбільш гострими?” кожен 2-й (41,5 \%) опитаний вказав “науководослідницьку роботу”; 39,6 \% - “міжнародна діяльність”; 37 \% - “контроль якості навчання студентів”. При цьому 27,1 \% (кожен 3-й) гострою проблемою в освітній сфері вважає видання навчально-методичної літератури з грифом МО3, МОН України та кожен 4-й респондент зазначив “можливість регулярно підвищувати кваліфікацію”. На питання “Чи потрібне особисто Вам підвищення кваліфікації?” 42,1 \% опитаних викладачів відповіли, що потребують підвищення професійної кваліфікації, 39 \% - в юридичній і 36 \% - у підвищенні педагогічної кваліфікації.

На питання "Наскільки, на Ваш погляд, ефективна введена в нашій академії система комплексних незалежних від кафедри іспитів на кафедрах фундаментальних дисциплін?” 77,6 \% опитаних відзначили, що система прогресивна і ефективна, дозволяє об’ єктивно оцінювати якість підготовки студентів, а кожен п’ятий підкреслив, що система усуває можливості корупції. Разом з тим, 17,7 \% підкреслили, що, на їх погляд, система неефективна, а 6 \% побоюються, що така система підриває авторитет викладача. На питання “Ваші професійні плани на майбутнє?” 50,3 \% опитаних викладачів уникли відповіді, на що є 2 варіанти пояснення: а) не хочуть ділитися планами з усіма; б) немає планів, немає мрії, не бачать перспектив. Серед планів на майбутнє вказані: захист докторської та кандидатської дисертацій, стажування за кордоном, пошук і отримання грантів, удосконалення мовної компетенції, засвоєння нових технологій професійної діяльності, підвищення кваліфікації, науково-дослідна робота, впровадження інтерактивних методик навчання студентів, інтернів, виконання кваліфікаційних вимог на посаду доцента, підготовка навчально-методичних посібників, зберегти “фізичну” здатність до професійної діяльності та інші.

На питання “Які, на Ваш погляд, проблеми для підвищення якості підготовки студентів в академії необхідно вирішувати в першу чергу?” 65,5 \% опитаних назвали “оснащеність сучасними технічними засобами навчання”; 61,6 \% - “додаткове матеріальне стимулювання викладачів залежно від результатів праці (за участь у розробці навчальних програм, підготовку якісних матеріалів для контролю знань та ін.)”; 47,9 \% - “активізація міжнародного співробітництва”, відсутність зацікавленості співробітників у результатах своєї праці (38,1%), оптимізація системи підвищення кваліфікації викладачів (32,6 \%).

Відповідаючи на запитання анкети “Чи влаштовує Вас: а) організація праці у вашому колективі; б) розподіл обов'язків між співробітниками; в) якість роботи Ваших колег; д) планування роботи на кафедрі; е) трудова дисципліна в колективі; ж) стиль і методи роботи керівника кафедри; з) стиль і методи роботи керівника деканату?”, виявилося, що більше половини всіх опитаних задоволені: стилем і методами роботи керівників (кафедрами, різних рівнів управління - 65,8 \%), деканатів (59,1 \%); трудовою дисципліною в колективі (65,5 \%); якістю роботи своїх колег (62,5 \%), плануванням роботи на кафедрі (62,8 \%). Але при цьому кожного 4-го (24,1 \%) не задовольняє розподіл обов’язків між співробітниками кафедри, 11,3 \% не задовольняють стиль і методи роботи керівника кафедри, 11,9 \% стиль і методи роботи керівників деканату. Більше половини опитаних викладачів задоволені соціальною престижністю своєї роботи, 54 \% 3 них визнані у професійному суспільстві, 48,2 \% задоволені визнанням колегами по роботі. Серед викладачів кожен третій опитаний (30,8 \%) брав участь у будьяких міжнародних науково-освітніх проектах. При цьому кожен 2-й респондент (50,6 \%) не має такого досвіду, але хотів би його отримати.

Незважаючи на те, що 32 \% опитаних викладачів досить добре володіють іноземною мовою для 
підготовки і викладання курсу іноземною мовою, 37,5 \% володіють іноземною мовою тільки нижче базового рівня і не готові викладати свій предмет іноземною мовою.

На питання “Наскільки ви задоволені прийнятою академією системою рейтингової оцінки викладача за рік?” тільки 22,9 \% опитаних повністю задоволені цією системою; кожен 2-й викладач (47,3 \%) скоріше задоволений, ніж ні, і кожен 3-й опитаний (26,2 \%) зовсім не задоволений.

Кожен 2-й викладач вважає, що в його посадовій інструкції повністю відображені права, обов’язки, методи заохочення і осуду відповідно до зазначеної посади; кожен 4-й опитаний (23,8 \%) підкреслив, що в його посадовій інструкції ці показники відображені частково; а кожен 5-й респондент зазначив, що на його посаду інструкція складена формально і не відображає весь спектр обов'язків, які виконує викладач.

На питання “Які, на Вашу думку, заходи могли б стати ефективними для підвищення якості підготовки студентів на Вашій кафедрі?” викладачі академії перерахували 264 заходи, які, на їх погляд, могли б стати ефективними для підвищення якості підготовки студентів. При їх узагальненні було сформовані такі блоки:

- покращення матеріально-технічної бази академії та кафедр сучасними технічними засобами (35,6 \% пропозицій);

- підвищення мотивації до навчання студентів, посилення дисципліни, вимога з боку деканату, введення платних відпрацювань (вніс кожен 5-й викладач);

- оптимізація навчального процесу на кафедрах: більше практичних навичок, роботи з пацієнтами, менше тестів, покращення знання базових дисциплін, підкреслили 19,7 \% опитаних;

- створення більш оптимальних умов для роботи викладачів вказав кожен 5-й опитаний;

- підвищити контроль за якістю роботи викладачів запропонували 16 \% респондентів (можливо, це були завідувачі кафедр).

В анкеті були також питання самооцінки здоров’я та здорового способу життя. Викладачі, будучи прикладом для студентів, не завжди стежать за своїм здоров'ям. Кожен 5-й викладач зазначив, що має проблеми зі здоров'ям, але практично 12 \% не займаються фізичною культурою для підтримки свого здоров’я. 19 \% має надлишкову масу тіла, кожен 10-й відповів, що курить. Разом з тим, тільки 10,7 \% респондентів постійно користуються спортивним комплексом академії, 16,2 \% - іноді, а 66,1 \% - ніколи ним не користуються з причин “немає часу”, “лінощі”, “далеко від дому” тощо. На запитання “Які пропозиції Ви хотіли б внести в схему рейтингової оцінки викладача?” 60,4 \% викладачами було внесено більш 100 пропозицій. Серед них такі: включити до рейтингу (позанавчальна робота в ДЕК, приймальній комісії, анкетування студентів), враховувати оцінку студентами якості викладання та рейтинг викладача серед студентів, враховувати викладання англійською мовою, оцінювати педагогічну майстерність викладача, додати бали за дослідження, за участь у міжнародних конференціях, за своєчасне отримання категорії, за лекції і доповіді на обласному, всеукраїнському рівні тощо.

В академії було проведено аналіз матеріалів анкетування викладачів, деякі дані були включені до серпневої доповіді 2015 р. На підставі анкетування за пропозиціями викладачів моніторинговою групою академії з метою удосконалення були допрацьовані умови рейтингу викладачів. Придбано навчально-наочні прилади для формування практичних навичок студентів, комп’ютерну техніку для поповнення потреб кафедр і забезпечення для викладачів умов роботи щодо підготовки методичних матеріалів, статей, тестових завдань тощо. Придбані сучасні підручники та навчальні посібники. Постійно вдосконалюється сайт академії і кожна кафедра має методичну і технічну допомогу для удосконалення своєї сторінки.

Висновки. В цілому за результатами анкетування можливо зробити висновки, що основна частина викладачів академії високо цінує “психологічний клімат” у колективі; зацікавлена в результатах своєї праці, в підвищенні якості підготовки майбутніх фахівців; задоволена працездатністю колективу кафедри, стилем і методами керівництва; гостро сприймає важливі для академії проблеми і внесла багато пропозицій з метою подальшого поліпшення організації роботи. Активно беруть участь у вирішенні питань оцінки своєї праці, рейтингу викладача, готові далі вдосконалювати свою професійну, юридичну та педагогічну кваліфікації. I в умовах, що склалися, адміністрація академії вживає всіх можливих заходів для поліпшення матеріальнотехнічної бази щодо забезпечення навчального процесу, поліпшення оснащення занять і науководослідних робіт, комп’ютеризації кафедр, бібліотек та соціального захисту працівників академії. 


\section{Список літератури}

1. Шляхи підвищення якості навчання на підставі моніторингу анкетування випускників академії / Г. В. Дзяк, Т. О. Перцева, С. В. Захаров, Г. В. Горбунова // Реалізація Закону України “Про вищу освіту” у вищій медичній та фармацевтичній освіті України : матеріали Всеукр. навч.-наук. конф. з міжнар. участю, присвяченої пам’яті ректора чл.-кор. НАМН України, проф. Леоніда Якимовича Ковальчука (Тернопіль, 21-22 травня 2015 р.). - Тернопіль : ТДМУ, 2015. - С. 43-44.
2. Особистісні якості та соціальні пріоритети викладачів / Г. В. Дзяк, Т. О. Перцева, Л. Ю. Науменко, Г. В. Горбунова // Впровадження нових технологій за кредитно-модульної системи організації навчального процесу у ВМ(Ф)НЗ III-IV рівнів акредитації : матеріали Всеукр. наук. навч.-метод. конф., присвяченої 55-річчю Тернопільського державного медичного університету (Тернопіль, 26-27 травня 2012 р.). - Тернопіль : ТДМУ, 2012. - С. 41-43. 